\title{
The lipopolysaccharide biosynthesis locus of Campylobacter jejuni 81116
}

\author{
Ben N. Fry, ${ }^{1} \dagger$ Victoria Korolik, ${ }^{2}$ Janna A. ten Brinke, ${ }^{1}$ \\ Maarten T. T. Pennings, ${ }^{2}$ Robert Zalm, ${ }^{1}$ Bart J. J. Teunis, ${ }^{1}$ \\ Peter J. Coloe ${ }^{2}$ and Bernard A. M. van der Zeijst ${ }^{1} \ddagger$
}

Author for correspondence: Bernard A. M. van der Zeijst. Tel: +31 302744164 . Fax: +31 302744439. e-mail: ben.van.der.zeijst@rivm.nl

\footnotetext{
1 Department of Bacteriology, Institute of Infectious Diseases and Immunology, Faculty of Veterinary Medicine, Utrecht University,

Yalelaan 1, $3584 \mathrm{CL}$

Utrecht, The Netherlands

2 Department of Applied Biology, RMIT GPO Box 2476V, Melbourne 3001, Australia
}

\begin{abstract}
Most Campylobacter jejuni strains express lipo-oligosaccharides. Some strains also express lipopolysaccharides (LPS), with 0-antigen-like carbohydrate repeats. C. jejuni 81116 expresses an LPS containing both lipo-oligosaccharides and O-antigen-like repeats, but nothing is known about the structure or sugar composition of these LPS species. A cosmid library of the genome of $C$. jejuni 81116 was constructed and probed with Campylobacter hyoilei genes involved in LPS synthesis. Five cosmids hybridized with the probe and two of these expressed C. jejuni 81116 LPS in Escherichia colf. By subcloning, a 16 kb DNA region was identified which contains the genetic information required to express C. jejuni LPS. DNA sequence analysis revealed 11 ORFs homologous to genes involved in LPS synthesis of other bacteria. They consisted of three homologues of sugar biosynthesis genes, two homologues of transport genes and six homologues of sugar transferases.
\end{abstract}

Keywords: Campylobacter jejuni, rfb gene cluster, lipo-oligosaccharide (LOS), lipopolysaccharide (LPS), O-antigen

\section{INTRODUCTION}

Campylobacter jejuni is an agent causing human enterocolitis and is the most common cause of bacterial diarrhoea in many countries (Tauxe, 1992). Symptoms most frequently seen are acute abdominal pain and inflammatory diarrhoea, often with fever (Butzler \& Skirrow, 1979). C. jejuni is also a commensal in the intestine of birds (Blaser \& Reller, 1981; Stern et al., 1988 ), which probably explains why it grows well at $42^{\circ} \mathrm{C}$, the body temperature of birds.

Lipopolysaccharides (LPS) are an abundant surface component of the outer membrane of Gram-negative bacteria. The LPS molecule consists of three distinct regions. Anchored in the outer membrane is the lipid A moiety, which is the endotoxic part of the LPS molecule.

†Present address: Department of Applied Biology and Biotechnology, Royal Melbourne Institute of Technology, 124 LaTrobe St, Melbourne, VIC 3000, Australia.

¥Present address: National Institute of Public Health and the Environment, Vaccine Division, PO Box 1, 3720 Bilthoven, The Netherlands.

Abbreviations: GalE, UDPgalactose 4-epimerase; KDO, ketodeoxy octulosonic acid; LOS, lipo-oligosaccharide; LPS, lipopolysaccharide.

The EMBL accession number for the complete $16 \mathrm{~kb}$ sequence reported in this paper is $\mathrm{Y} 11648$.
Attached to the lipid A is the core, a branched-chain oligosaccharide linked to a ketodeoxy octulosonic acid (KDO) molecule, which has an inner and an outer part. Specific for the inner core is the presence of KDO and heptose residues, which are not found in the outer core. Extending from the cell surface is the O-antigen, a repeat of 10-30 oligosaccharides composed of 1-5 sugar residues (Schnaitman \& Klena, 1993). Bacterial Oantigen protects the organism against complement and other serum components (Hackett et al., 1987; Joiner et al., 1986) and is involved in resistance to microbicidal human polymorphonuclear leukocytes (Stinavage $e t$ al., 1989).

A variant of the LPS molecule, seen in bacteria like Neisseria spp., Haemophilus spp. and Bordetella spp., is the lipo-oligosaccharide (LOS) molecule (Inzana et al., 1985; Jennings et al., 1980; Ray et al., 1991), which lacks the O-antigen polymer. C. jejuni strains synthesize LOS molecules. In addition, some strains also possess polysaccharide repeats (Preston \& Penner, 1987). In this paper, the term LPS will be used to indicate both saccharide structures of Campylobacter (LOS or LPS containing additional polysaccharide repeats). The LPS molecules of Campylobacter have been shown to have endotoxic properties (Branquinho et al., 1983; Naess \& 


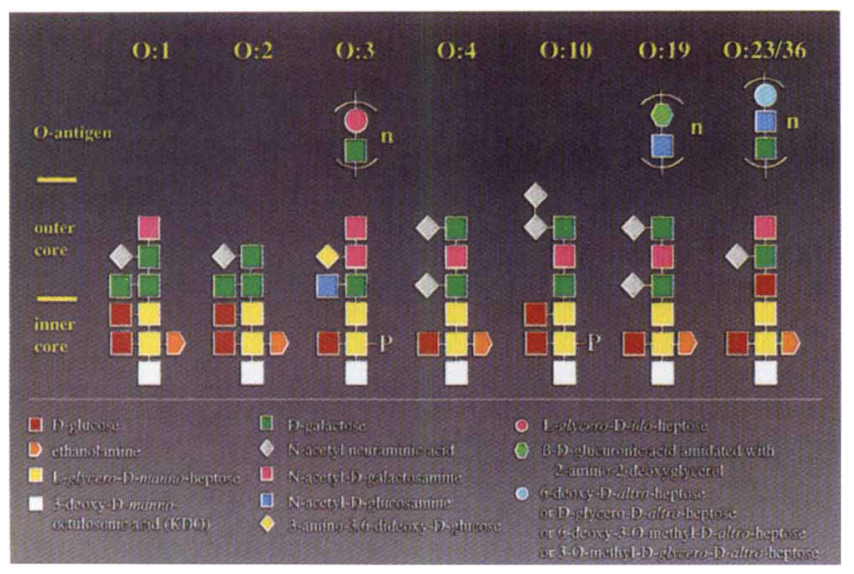

Fig. 1. Known structures of core molecules and O-antigen-like polysaccharides from Campylobacter jejuni strains. $0: 1$ (Aspinall et al., 1993c), 0:2 (Aspinall et al., 1993b), 0:3 (Aspinall et al., 1995a), 0:4 (Aspinall et al., 1993c), 0:10 (Salloway et al., 1996), 0:19 (Aspinall et al., 1994a, b), 0:23 and 0:36 (Aspinall et al., 1992a, 1993c). The serotypes are shown. ' $n$ ' indicates that the oligosaccharide is repeated, forming an $O$-antigen-like polysaccharide. ' $P$ ' denotes $a$ phosphate group.

Hofstad, 1984). Furthermore they have been reported to be important as adhesins (McSweegan \& Walker, 1986) and they may play a role in antigenic variation, as the bacteria have the ability to shift the LPS antigenic composition (Mills et al., 1992).

The sugar composition and structure of the core oligosaccharide from several C. jejuni strains, belonging to eight serotypes, have been analysed (Fig. 1; Aspinall et al., 1993b, c, 1994b, 1995a ; Salloway et al., 1996). The presence of $\mathrm{N}$-acetylneuraminic acid (NeuNAc) is surprising, as it is not usually found in prokaryotes. These NeuNAc residues resemble gangliosides when attached by $\beta-2,3$ linkages to $D-G a l$ (Aspinall et al., 1992b, 1993c). This molecular mimicry is thought to play a role in the neuropathological autoimmune diseases Guillain-Barré syndrome and Miller-Fisher syndrome (Salloway et al., 1996; Schwerer et al., 1995). In Neisseria and Haemophilus, sialylation of LPS plays a role in pathogenicity by enhancing serum resistance (Demarco de Hormaeche $e t$ al., 1991; Moxon \& Maskell, 1992). The role of sialylation of the Campylobacter LPS in pathogenicity has not yet been determined.

For many bacteria, the LPS core structure is highly conserved within a genus (Jansson et al., 1981). The core oligosaccharide structure of C. jejuni however is highly variable, although the sugar composition is not very different between strains (Fig. 1). Limited variability has also been observed for the core oligosaccharide from Neisseria and Haemophilus (Mandrell \& Apicella, 1993; Pavliak et al., 1993), although not to the extent seen in C. jejuni. This variability in the C. jejuni LPS core explains the ability of the Penner serotyping system (Penner, 1988; Penner \& Hennessy, 1980) to discriminate between strains with LOS-type LPS.
The O-antigen repeats of C. jejuni serotypes $\mathrm{O}: 3, \mathrm{O}: 19$, $\mathrm{O}: 23$ and $\mathrm{O}: 36$ have been analysed so far (Aspinall $e t$ al., 1992a, 1994a, 1995a). They consist of only two or three sugar species (Fig. 1). The position of the core oligosaccharide to which the $\mathrm{O}$-antigen is attached has not been determined; the inner core heptose-KDO region has been suggested (Aspinall et al., 1994a), but $C$. jejuni serotype $\mathrm{O}: 3$ synthesizes a polysaccharide, consisting of a disaccharide repeat of L-glycero-D-idoheptose $1 \rightarrow 4 \mathrm{Gal}$, which is not covalently linked to the LPS core (Aspinall et al., 1995a).

The metabolic pathways and enzymes required to synthesize the LPS molecules have not yet been characterized. Rapid progress in the study of LPS synthesis in other bacteria has been made by a genetic approach in combination with knowledge of the structure of LPS. Understanding LPS genetics for C. jejuni would allow more insight into the role of LPS in infection and colonization, through the ability to create specific mutants. Moreover, it would enable a better understanding of the mechanism of LPS synthesis in C. jejuni.

C. jejuni strain 81116 was originally isolated from a human water-borne outbreak of gastroenteritis (Palmer et al., 1983). In this paper we report the cloning of the LPS gene cluster, which is located on a $16 \mathrm{~kb}$ chromosomal DNA fragment, from this pathogenic strain. This region, when expressed in Escherichia coli, gives rise to an LPS which reacts with the C. jejuni Penner antiserum specific for serotype 6 . The nucleotide sequence of this region was also determined.

\section{METHODS}

Bacterial strains and plasmids. The bacterial strains and plasmids used in this study are listed in Table 1. C. jejuni strains were grown under microaerophilic conditions on Skirrow agar medium (Skirrow, 1977) at $42^{\circ} \mathrm{C}$ for 24 h. E. coli was grown in LB broth or agar for $16 \mathrm{~h}$ at $37^{\circ} \mathrm{C}$. Antibiotic concentrations used were as follows: kanamycin (Sigma), $30 \mu \mathrm{g} \mathrm{ml}^{-1}$; tetracycline (Sigma), $20 \mu \mathrm{g} \mathrm{ml}^{-1}$; ampicillin (Centrafarm), $100 \mu \mathrm{g} \mathrm{ml}^{-1}$.

DNA manipulation. DNA isolations, restriction enzyme digestions and DNA ligations were performed as described by Ausubel et al. (1995). Restriction enzymes, alkaline phosphatase and a nested deletion kit were obtained from Pharmacia and used according to the manufacturer's instructions. Plasmid DNA purification for sequencing reactions was performed by using the Flexiprep plasmid kit (Pharmacia) or the Qiagen plasmid kit (Qiagen). DNA fragments for subcloning and probes were isolated from agarose gels using the Geneclean II kit (Bio101).

Construction of the C. jejuni 81116 genomic library. Highmolecular-mass genomic DNA of C. jejuni 81116 was partially cleaved using Sau3AI and fragments were size-fractionated by sucrose-gradient centrifugation (Sambrook et al., 1982). Fragments of $25-35 \mathrm{~kb}$ were selected and cloned into the unique $B g l$ II site in the kanamycin-resistance gene of a $21 \mathrm{~kb}$ alkalinephosphatase-treated cosmid vector pLA2917 (Allen \& Hanson, 1985). The ligated mixture (a ratio of two vector molecules to one chromosomal fragment) was then packaged $(0.5 \mu$ g ligation mix to $50 \mu$ l packaging mix $)$ with Packagene $\lambda$ particle packaging mix (Promega) and the mixture was 
Table 1. Bacterial strains and plasmids used in this work

\begin{tabular}{|c|c|c|}
\hline Strain or plasmid & Description & Reference \\
\hline \multicolumn{3}{|l|}{ C. jejuni strains } \\
\hline 81116 & Penner 6 serotype & Palmer et al. (1983) \\
\hline \multicolumn{3}{|l|}{ E. coli strains } \\
\hline HB101 & $\begin{array}{l}\Delta(g p t-p r o A) 62 \text { leuB6 thi-1 lacY1 bsdS } S_{\mathrm{B}} 20 \text { recA rpsL20 }\left(\mathrm{Str}^{\mathrm{R}}\right) \text { ara-14 } \\
\text { galK2 xyl-5 mtl-1 subE44 mcrB }{ }_{\mathrm{B}}\end{array}$ & Boyer \& Roulland-Dussoix (1969) \\
\hline DH5 $\alpha$ & $\begin{array}{l}\mathrm{F}^{\prime} / \text { endA1 hsdR17 }\left(r_{\mathbf{k}}^{-} m_{\mathrm{k}}^{+}\right) \text {subE44 thi-1 recA1 gyrA }\left(\mathrm{Nal}^{\mathrm{R}}\right) \text { relA1 } \\
\Delta(\text { lacZYA-argF }) \mathrm{U} 169(\varphi 80 \text { lacZ } \Delta M 15)\end{array}$ & Hanahan (1983) \\
\hline $\mathrm{S}_{\varphi} 874$ & $\mathrm{~K}-12 \Delta(s b c B-r f b) 86$ lacZ4053 trp-355 upp-12 relA1 rpsL150 & Neuhard \& Thomassen (1976) \\
\hline O111 & & Bray $\langle 1945\rangle$ \\
\hline \multicolumn{3}{|l|}{ Plasmids } \\
\hline pBR322 & Cloning vector & Bolivar et al. (1977) \\
\hline $\mathrm{pBl}$ & Sequencing vector pBluescript KS M13+ & Short et al. (1988) \\
\hline pUC18 & Sequencing vector & Yanisch-Perron et al. (1985) \\
\hline pLA2917 & Cosmid vector & Allen \& Hanson (1985) \\
\hline pBT9502 & pLA2917 containing a $25 \mathrm{~kb}$ fragment from C. jejuni 81116 & This study \\
\hline pBT9503 & pLA2917 containing a $30 \mathrm{~kb}$ fragment from C. jejuni 81116 & This study \\
\hline pBT9504 & pLA2917 containing a $29 \mathrm{~kb}$ fragment from C. jejuni 81116 & This study \\
\hline pBT9505 & pLA2917 containing a $27 \mathrm{~kb}$ fragment from C. jejuni 81116 & This study \\
\hline рBT9506 & pLA2917 containing a $25 \mathrm{~kb}$ fragment from C. jejuni 81116 & This study \\
\hline pBTLPS & Subclone (BglII) of pBT9502 containing a $16 \mathrm{~kb}$ fragment in pBR322 & This study \\
\hline pBF81 & $7 \mathrm{~kb}$ ClaI fragment from pBT9502 in $\mathrm{pBl}$ & This study \\
\hline pBF84 & $3.2 \mathrm{~kb}$ BglII fragment from $\mathrm{pBT} 9502$ in $\mathrm{pBl}$ & This study \\
\hline pBF92 & $4.5 \mathrm{~kb} B g l \mathrm{II}$ fragment from $\mathrm{pBT} 9502$ in $\mathrm{pBl}$ & This study \\
\hline pBF71 & $3 \mathrm{~kb}$ Sau3A fragment from pBT9502 in pUC18 & This study \\
\hline pBF77 & $1.4 \mathrm{~kb}$ HindIII fragment from $\mathrm{pBT} 9502$ in $\mathrm{pBl}$ & This study \\
\hline
\end{tabular}

transduced into the host $E$. coli $\mathrm{HB} 101$ as recommended by the manufacturers. Of the resulting transformants, 600 were taken to assemble the genomic library, ensuring that the complete C. jejuni genome of $1600 \mathrm{~kb}$ was present.

Library screening by Southern blot analysis. The library was plated onto $\mathrm{LB}$ plates and grown overnight at $37^{\circ} \mathrm{C}$. The bacteria were transferred to nylon membranes (Hybond-N; Amersham) and lysed on Whatman $3 \mathrm{MM}$ paper saturated with $2 \times$ SSPE, $5 \%$ SDS. The DNA was fixed by microwaving the filters for $2.5 \mathrm{~min}$ at $650 \mathrm{~W}$. The filters were prehybridized for $2 \mathrm{~h}$ in hybridization mix $(6 \times$ SSPE, $5 \times$ Denhardt's, $0.5 \%$ SDS) with $0 \cdot 1 \mathrm{mg}$ herring sperm DNA ml $\mathrm{m}^{-1}$ at $60^{\circ} \mathrm{C}$. The insert from pBT9105 (pBR322 with an $11.8 \mathrm{~kb}$ EcoRV fragment from Campylobacter byoilei RMIT-32A containing several genes showing homology with genes involved in LPS synthesis, including a rfbP-like gene; Korolik et al., 1997) was labelled with ${ }^{32} \mathrm{P}$ using a random-priming labelling kit (Amersham). After boiling the probe for $3 \mathrm{~min}$, it was added to the filters in the hybridization mix and hybridized overnight at $60^{\circ} \mathrm{C}$. The filters were washed twice with $2 \times \mathrm{SSPE}, 0.1 \%$ SDS for $15 \mathrm{~min}$ at $60^{\circ} \mathrm{C}$ and exposed to Fuji RX film overnight.

Subcloning of the $C$. jejuni LPS coding region. Recombinant cosmid pBT9502 DNA was partially cleaved with BglII. The resulting fragments were subcloned into BamHI-cleaved, alkaline-phosphatase-treated plasmid vector pBR322 (Bolivar et al., 1977) and transformed into E. coli HB101.

DNA sequence analysis. The sequence of the cloned DNA was determined by the dideoxy chain-termination method (Sanger et al., 1977) with an Automated laser fluorescent DNA sequencer (Pharmacia), the autoread sequencing kit using T7
DNA polymerase (Pharmacia) and fluorescein-labelled nucleotide primers (Pharmacia). PC/GENE 6.70 (Korn \& Queen, 1984) was used to analyse nucleotide and amino acid sequences, which were compared to databases available at GenomeNet using the BLAST program (Altschul et al., 1990). The Macaw program (Lawrence et al., 1993) was used for multiple sequence alignment.

LPS isolation, PAGE, silver staining and immunoblotting. Cell envelopes were isolated following the procedure of Lugtenberg et al. (1975) and treated with proteinase $\mathrm{K}$ for $1 \mathrm{~h}$ at $56^{\circ} \mathrm{C}$. The isolated LPS was resolved by Tricine-SDS-PAGE (Lesse $e t$ al., 1990; Schagger \& von Jagow, 1987) and analysed by silver staining (Tsai \& Frasch, 1982) and Western blotting (Sambrook et al., 1982). Penner 6 antiserum was used in immunoblotting diluted $1: 1000$ in PBS containing $5 \%$ skimmed milk and 0.3\% Tween 20. Goat anti-rabbit alkalinephosphatase-conjugated immunoglobulins (Promega) were used as the second antibody diluted 1:5000 in PBS containing $5 \%$ skimmed milk and $0.3 \%$ Tween 20 . The bound phosphatase was visualized with NBT/BCIP (nitro blue tetrazolium/5-bromo-4-chloro-3-indolyl phosphate). The Multimark multi-coloured standard (Novel Experimental Technology) was used as a molecular-mass marker.

\section{RESULTS}

\section{Isolation of the DNA region involved in LPS synthesis}

A genomic cosmid library of C. jejuni 81116 (Newell et al., 1985; Palmer et al., 1983) was constructed and screened by Southern hybridization with the $r f b P$ gene 


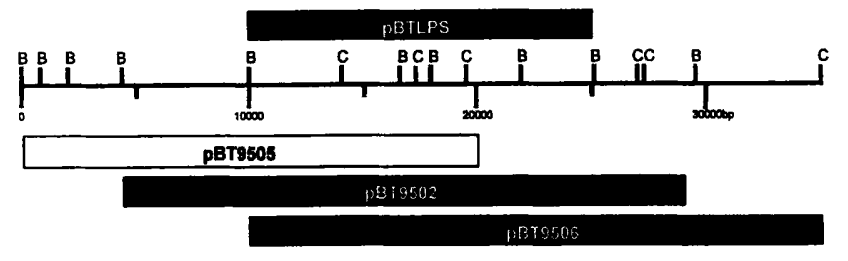

Fig. 2. Restriction map of the genomic region of $C$. jejuni 81116 encoding the synthesis of $\mathrm{O}$-antigen. The inserts of cosmids pBT9502, pBT9505 and pBT9506 are shown as bars. The insert of plasmid pBTLPS is also shown. Black bars indicate clones that express O-antigen in E. coli. C and B are abbreviations for Clal and $B g / l l$ respectively.

from C. byoilei (Korolik et al., 1997). This gene is homologous to genes involved in transferring the first sugar of the $\mathrm{O}$-antigen subunit to the lipid precursor undecaprenol phosphate. Five hybridizing clones were isolated. The cosmids contained in these strains were designated pBT9502-pBT9506 (Table 1). Restriction analysis showed that pBT9502, pBT9505 and pBT9506 contained overlapping inserts (Fig. 2). The three clones carrying these overlapping cosmids were tested for expression of C. jejuni LPS antigens by colony blotting. Both E. coli/pBT9502 and E. coli/pBT9506 reacted with Penner 6 antiserum in a Western blot.

\section{LPS analysis}

The silver-stained C. jejuni 81116 LPS showed one band of $6 \mathrm{kDa}$ after separation by Tricine-SDS-PAGE. This size is in accordance with LPS isolated from other Campylobacter strains. Using the Tricine-SDS-PAGE system allows the use of protein markers to estimate the molecular mass of LPS components (Lesse et al., 1990), as opposed to the standard glycine-buffer system in which the LPS components do not migrate as a function of their molecular masses. Moreover, aggregates were observed for C. jejuni 81116 LPS when the standard glycine-SDS-PAGE method of Laemmli (1970) was used (data not shown); this was never seen using the TricineSDS-PAGE method.

The $E$. coli strains carrying recombinant cosmids showed different LPS profiles when stained with silver. In the control lane, E. coli/pLA2917, three bands around $5.5 \mathrm{kDa}$ and two bands around $4 \mathrm{kDa}$ were visible. $E$. coli/pBT9505 LPS demonstrated the same pattern (data not shown). E. coli/pBT9502 and E. coli/pBT9506 LPS showed identical patterns with additional bands of 4.5 , $6 \cdot 5,7.5$ and $8 \mathrm{kDa}$ compared to E. coli/pLA2917. The LPS from $E$. coli/pBT9502 is shown in Fig. 3. The changed LPS pattern shows that the cloned DNA region is involved in LPS synthesis.

Western blotting analysis using Penner 6 antiserum demonstrated that $C$. jejuni 81116 LPS is of the smooth type, with a high-molecular-mass $\mathrm{O}$-antigen-specific ladder pattern between 6 and $40 \mathrm{kDa}$. LPS isolated from E. coli/pBT9502 and E. coli/pBT9506(not shown) gave (a)

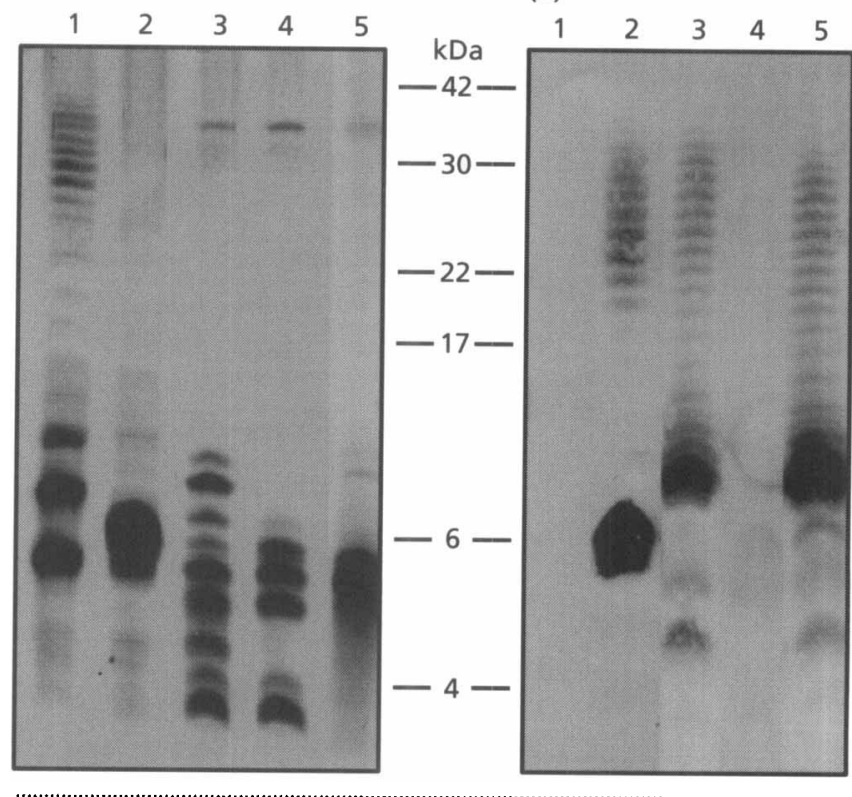

Fig. 3. LPS profiles in Tricine-SDS-PAGE. (a) Silver-stained samples. (b) Western blots reacted with Penner 6 antiserum. Lanes: 1, E. coli 0111; 2, C. jejuni 81116; 3, E. coli HB101(pBT9502); 4, E. coli HB101(pLA2917); 5, E. coli HB101 (pBTLPS).

identical profiles, i.e. an O-antigen ladder pattern with immunoreactive bands between 10 and $45 \mathrm{kDa}$. This complex appeared to have a higher molecular mass than that of C. jejuni 81116 LPS. This may be explained by the fact that the lipid A-core complex of $E$. coli is used as a carrier for the $C$. jejuni O-antigen subunits. As expected, the C. jejuni O-antigen expressed in E. coli does not stain with silver. LPS prepared from $E$. coli/pBT9505 did not react with Penner 6 antiserum (data not shown).

\section{Further definition of the LPS-xpressing DNA region}

The smallest insert still able to encode the complete ladder structure reacting with Penner 6 antiserum was $16 \mathrm{~kb}$; it was subcloned into the pBR322 plasmid vector. The plasmid containing this insert was named pBTLPS (Figs 2 and 3). To exclude possible complementation of the E. coli HB101 LPS genes by the C. jejuni genes, pBT9502 and pBTLPS were also expressed in E. coli $\mathrm{S} \varphi 874$, a strain lacking all genes involved in O-antigen synthesis. LPS isolated from these $\mathrm{S} \varphi 874$ strains showed the same $\mathrm{O}$-antigen ladder pattern reacting with Penner 6 antiserum (data not shown).

\section{DNA sequence analysis}

Fragments of the insert of plasmid pBTLPS, generated by the restriction endonucleases BglII, ClaI, HindIII and Sau3AI, were subcloned into sequencing vectors. Nested deletions and subcloning of these fragments allowed the 


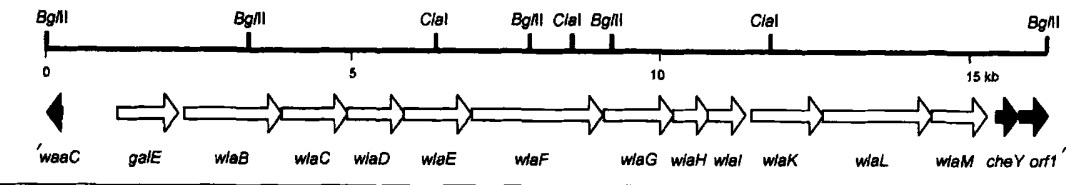

Fig. 4. The $16 \mathrm{~kb}$ region containing the wla cluster (open arrows) and flanking genes of C. jejuni 81116. The waaC and orf1 ORFs are incomplete on this fragment.

Table 2. Characteristics of the found ORFs

\begin{tabular}{|c|c|c|c|c|c|c|c|}
\hline ORF & Translation start* & Spacing $\dagger$ & Position (nt) & $\begin{array}{l}\text { Size } \\
\text { (aa) }\end{array}$ & $\begin{array}{c}\text { Molecular } \\
\text { mass } \\
(\mathrm{kDa})\end{array}$ & pI & $\begin{array}{c}\mathrm{G}+\mathrm{C} \\
(\mathrm{mol} \%)\end{array}$ \\
\hline$w a a C \ddagger$ & aatattAGGcttttaATGaaa & 5 & $254-1$ & $>84$ & $>9.7$ & $9 \cdot 8$ & $27 \cdot 4$ \\
\hline galE & gaaaAAGGAatgatgATGaaa & 6 & 1169-2155 & 328 & $36 \cdot 8$ & $5 \cdot 9$ & $34 \cdot 4$ \\
\hline$w l a B$ & tgattGGGAaaaacaGTGcta & 6 & $2149-3843$ & 564 & $64 \cdot 5$ & $9 \cdot 2$ & $28 \cdot 4$ \\
\hline wlaC & taAAGAGGAgaaatgATGaaa & 6 & $3843-4919$ & 358 & $41 \cdot 1$ & $8 \cdot 4$ & $30 \cdot 5$ \\
\hline wlaD & tagtcGAGGTtaaaaATGcct & 5 & $4912-5841$ & 309 & $35 \cdot 5$ & $9 \cdot 1$ & $29 \cdot 7$ \\
\hline wlaE & aattcgGGTGgctttATGcaa & 5 & $5829-6926$ & 365 & $41 \cdot 3$ & 8.7 & $29 \cdot 2$ \\
\hline wlaF & ttattAGGAtaaaagATGttg & 6 & $6930-9071$ & 713 & $82 \cdot 2$ & $8 \cdot 3$ & $29 \cdot 7$ \\
\hline$w l a G$ & attTAAGGGttgaaaATGaga & 6 & 9081-10211 & 376 & $42 \cdot 9$ & $9 \cdot 2$ & $30 \cdot 0$ \\
\hline wlaH & atAGGGtaattaagaATGtat & 9 & $10204-10806$ & 200 & $23 \cdot 1$ & 9.7 & $32 \cdot 5$ \\
\hline wlal & taagcaAAGAaggccATGtta & 5 & $10772-11383$ & 203 & $22 \cdot 1$ & $9 \cdot 0$ & $31 \cdot 7$ \\
\hline wlaK & tacaAAGGAtaaatcATGaga & 6 & $11481-12641$ & 386 & $43 \cdot 8$ & $6 \cdot 2$ & $30 \cdot 7$ \\
\hline wlaL & gcataAAGGcttaaaATGatt & 6 & $12643-14415$ & 590 & $66 \cdot 7$ & $7 \cdot 8$ & $30 \cdot 4$ \\
\hline wlaM & taaagAAGGcatataATGtat & 5 & $14415-15308$ & 297 & $33 \cdot 9$ & 6.9 & $29 \cdot 9$ \\
\hline cheY & tgaaAGGAcgaaattGTGaaa & 7 & $15421-15813$ & 130 & $14 \cdot 4$ & $5 \cdot 0$ & $34 \cdot 4$ \\
\hline orf1 $\neq$ & tttttAAAAttctaaATGcaa & 6 & $15836-16293$ & $>152$ & $>18 \cdot 0$ & $6 \cdot 5$ & $28 \cdot 2$ \\
\hline
\end{tabular}

* Potential Shine-Dalgarno sequences and start codons (bold) are capitalized.

† Spacing between Shine-Dalgarno sequence and start codon.

‡Incompletely characterized ORF.

sequencing of the complete $16 \mathrm{~kb}$ region. To demonstrate continuity of adjacent but non-overlapping fragments, specifically primed sequences were generated.

Sequence analysis of the insert from pBTLPS showed that it contains 13 complete and two incomplete ORFs (Fig. 4; Table 2). Twelve ORFs showed homology to genes involved in LPS synthesis (Table 2) and were named galE and wlaB-wlaM (wla genes), according to the newly proposed bacterial polysaccharide gene nomenclature (Reeves et al., 1996). The remaining complete ORF was that of the chemotaxis gene cheY from C. jejuni, which is not thought to be involved in LPS synthesis. The incomplete ORF at the $5^{\prime}$ terminus was similar to waa $\mathrm{C}$ genes and was therefore named waaC. At the $3^{\prime}$ end, an incomplete ORF without homology was found. waa $C$ is transcribed in the opposite direction to the other genes (Fig. 4). Not all the genes start with ATG codons preceded by typical Shine-Dalgarno sequences. $w$ laB and cheY have the putative start codon GUG (Table 2); to our knowledge, this is the first time this start codon has been suggested for a Campylobacter gene. As only a few Campylobacter genes have been identified, not much is known about the promoter consensus sequences. Using the $E$. coli $\sigma^{70}$ promoter consensus sequence, weak putative promoter sites were recognized along the sequence, which were located upstream of the waaC, the galE and the cheY genes. galE and $w l a B-w l a M$ are very closely spaced, with most of the designated ORFs showing overlap (Table 2). The largest spacing between two ORFs (97 bp) was found between genes $w l a I$ and $w l a K$. No putative promoter sequences were found within this spacing. All these genes have the same transcriptional direction and therefore it is likely they are transcribed as a single operon. No putative $r h o$-independent terminator-like hairpin loops were found. All ORFs possessed a $\mathrm{G}+\mathrm{C}$ content between 28 and $34 \mathrm{~mol} \%$ (Table 2), which is consistent with the low $\mathrm{G}+\mathrm{C}$ content of Campylobacter spp. of $30 \mathrm{~mol} \%$.

The characteristics of the genes within the analysed region will be discussed in the order in which they are present, starting with waaC. The BLAST algorithm (Altschul et al., 1990) was used to find proteins homologous to the deduced gene products (Table 3 ).

waac. The deduced partial protein sequence is homologous to the N-terminal regions of LPS heptosyltransferases $-\mathrm{I}$, which transfer a heptose residue to the KDO molecule, initiating the synthesis of the inner core (Ray \& Raetz, 1987). At least four other genes adjacent to waaC are similar to genes involved in inner core synthesis (data not shown). Therefore, waaC may be the first of a gene cluster involved in inner core synthesis. 
Table 3. Deduced proteins present in the $C$. jejuni wla region and their homologues

\begin{tabular}{|c|c|c|c|c|c|}
\hline $\begin{array}{l}\text { C. } j \text { jejuni } \\
\text { protein }\end{array}$ & $\begin{array}{l}\text { Similar } \\
\text { protein }\end{array}$ & Organism & Function & $\begin{array}{c}\text { Identity/ } \\
\text { similarity }(\%)^{*}\end{array}$ & $\begin{array}{c}\text { Accession } \\
\text { no. }\end{array}$ \\
\hline WaaC $†$ & $\begin{array}{l}\text { RfaC } \\
\text { RfaC } \\
R f a C \\
\text { RfaC }\end{array}$ & $\begin{array}{l}\text { Escherichia coli } \\
\text { Neisseria gonorrhoeae } \\
\text { Bordetella pertussis } \\
\text { Salmonella typhimurium }\end{array}$ & $\begin{array}{l}\text { Heptosyltransferase I } \\
\text { Heptosyltransferase I } \\
\text { Heptosyltransferase I } \\
\text { Heptosyltransferase I }\end{array}$ & $\begin{array}{l}28 \cdot 6 / 51 \cdot 2 \\
28 \cdot 6 / 51 \cdot 2 \\
28 \cdot 6 / 48 \cdot 8 \\
26 \cdot 2 / 52 \cdot 4\end{array}$ & $\begin{array}{l}\mathrm{P} 24173 \\
\mathrm{~S} 60783 \\
\mathrm{X} 90711 \\
\mathrm{P} 26469\end{array}$ \\
\hline GalE & $\begin{array}{l}\text { GalE } \\
\text { GalE } \\
\text { GalE }\end{array}$ & $\begin{array}{l}\text { Haemophilus influenzae } \\
\text { Neisseria meningitidis } \\
\text { Escherichia coli }\end{array}$ & $\begin{array}{l}\text { UDPglucose 4-epimerase } \\
\text { UDPglucose 4-epimerase } \\
\text { UDPglucose 4-epimerase }\end{array}$ & $\begin{array}{l}37 \cdot 5 / 52 \cdot 4 \\
36 \cdot 3 / 53 \cdot 1 \\
36 \cdot 0 / 52 \cdot 2\end{array}$ & $\begin{array}{l}\text { A64063 } \\
\text { S39638 } \\
\text { P09147 }\end{array}$ \\
\hline WlaB & $\begin{array}{l}\text { HetA } \\
\text { HlyB } \\
\text { HlyB } \\
\text { MsbA } \\
\text { ValA }\end{array}$ & $\begin{array}{l}\text { Anabaena sp. } \\
\text { Escherichia coli } \\
\text { Actinobacillus pleuropneumoniae } \\
\text { Escherichia coli } \\
\text { Francisella novicida }\end{array}$ & $\begin{array}{l}\text { Polysaccharide involvement } \\
\text { Export haemolysin } \\
\text { Export haemolysin } \\
\text { Export } \ddagger \\
\text { Secretion LPS }\end{array}$ & $\begin{array}{l}30 \cdot 1 / 48 \cdot 7 \\
30 \cdot 1 / 46 \cdot 2 \\
27 \cdot 5 / 44 \cdot 0 \\
24 \cdot 3 / 43 \cdot 3 \\
23 \cdot 4 / 41 \cdot 5\end{array}$ & $\begin{array}{l}\text { P22638 } \\
\text { P08716 } \\
\text { P26760 } \\
\text { P27299 } \\
\text { L17003 }\end{array}$ \\
\hline WlaC & $\begin{array}{l}\text { TrsD } \\
\text { AmsD } \\
\text { EpsG }\end{array}$ & $\begin{array}{l}\text { Yersinia enterocolitica } \\
\text { Erwinia amylovora } \\
\text { Streptococcus thermophilus }\end{array}$ & $\begin{array}{l}\text { Glycosyltransferase } \ddagger \\
\text { Glycosyltransferase } \neq \\
\text { Glycosyltransferase } \neq\end{array}$ & $\begin{array}{l}28 \cdot 8 / 47 \cdot 0 \\
27 \cdot 4 / 44 \cdot 8 \\
26 \cdot 8 / 40 \cdot 8\end{array}$ & $\begin{array}{l}\text { S51263 } \\
\text { S52144 } \\
\text { U40830 }\end{array}$ \\
\hline WlaD & $\begin{array}{l}\text { Orf8.7 } \\
\text { TrsB } \\
\text { EpsI } \\
\text { SpsA }\end{array}$ & $\begin{array}{l}\text { Yersinia pseudotuberculosis } \\
\text { Yersinia enterocolitica } \\
\text { Streptococcus thermophilus } \\
\text { Bacillus subtilus }\end{array}$ & $\begin{array}{l}\text { Abequosyltransferase } \ddagger \\
\text { Glycosyltransferase } \ddagger \\
\text { Glycosyltransferase } \neq \\
\text { Polysaccharide synthesis }\end{array}$ & $\begin{array}{l}27 \cdot 2 / 38 \cdot 9 \\
23 \cdot 3 / 42 \cdot 4 \\
23 \cdot 0 / 38 \cdot 8 \\
22 \cdot 2 / 41 \cdot 0\end{array}$ & $\begin{array}{l}\text { L01777 } \\
\text { S51261 } \\
\text { U40830 } \\
\text { P39621 }\end{array}$ \\
\hline WlaE & $\begin{array}{l}\text { AmsD } \\
\text { TrsD } \\
\text { TrsE } \\
\text { CapH }\end{array}$ & $\begin{array}{l}\text { Erwinia amylovora } \\
\text { Yersinia enterocolitica } \\
\text { Yersinia enterocolitica } \\
\text { Staphylococcus aureus }\end{array}$ & $\begin{array}{l}\text { Glycosyltransferase } \neq \\
\text { Glycosyltransferase } \\
\text { Glycosyltransferase } \\
\text { Glycosyltransferase }\end{array}$ & $\begin{array}{l}25 \cdot 1 / 41 \cdot 3 \\
24 \cdot 9 / 40 \cdot 5 \\
25 \cdot 6 / 40 \cdot 1 \\
23 \cdot 1 / 37 \cdot 8\end{array}$ & $\begin{array}{l}\text { S52144 } \\
\text { S51263 } \\
\text { S51264 } \\
\text { U10927 }\end{array}$ \\
\hline WlaF & $\begin{array}{l}\text { STT-3 } \\
\text { Wzy (Rfc) } \\
\text { STT3 }\end{array}$ & $\begin{array}{l}\text { Caenorbabditis elegans } \\
\text { Escherichia coli } \\
\text { Saccharomyces cerevisiae }\end{array}$ & $\begin{array}{l}\text { Oligosaccharyltransferase } \\
\text { O-antigen polymerase } \\
\text { Oligosaccharyltransferase }\end{array}$ & $\begin{array}{l}19 \cdot 5 / 35 \cdot 9 \\
18 \cdot 8 / 39 \cdot 7 \\
16 \cdot 3 / 34 \cdot 5\end{array}$ & $\begin{array}{l}\text { P46975 } \\
\text { P37748 } \\
\text { JC4355 }\end{array}$ \\
\hline WlaG & $\begin{array}{l}\text { CpsF } \\
\text { RfbF } \\
\text { RfpB } \\
\text { RfbF }\end{array}$ & $\begin{array}{l}\text { Proteus mirabilis } \\
\text { Serratia marescens } \\
\text { Shigella dysenteriae } \\
\text { Klebsiella pneumoniae }\end{array}$ & $\begin{array}{l}\text { Glycosyltransferase } \\
\text { Galactantransferase } \neq \\
\text { Galactosyltransferase } \\
\text { Galactantransferase }\end{array}$ & $\begin{array}{l}30 \cdot 8 / 48 \cdot 1 \\
27 \cdot 1 / 41 \cdot 2 \\
26 \cdot 6 / 44 \cdot 7 \\
26 \cdot 1 / 41 \cdot 5\end{array}$ & $\begin{array}{l}\text { L36873 } \\
\text { L34167 } \\
\text { S27671 } \\
\text { L31762 }\end{array}$ \\
\hline WlaH & $\begin{array}{l}\text { WbaP (RfbP) } \\
\text { WbaP (RfbP) } \\
\text { EpsE } \\
\text { ExoY }\end{array}$ & $\begin{array}{l}\text { Salmonella enterica } \\
\text { Haemophilus infuenzae } \\
\text { Streptococcus thermophilus } \\
\text { Rhizobium sp. }\end{array}$ & $\begin{array}{l}\text { Galactosyltransferase first step } \\
\text { Galactosyltransferase } \ddagger \\
\text { Galactosyltransferase first step } \\
\text { Galactosyltransferase first step } \ddagger\end{array}$ & $\begin{array}{l}39 \cdot 5 / 55 \cdot 5 \\
38 \cdot 5 / 53 \cdot 0 \\
36 \cdot 0 / 53 \cdot 0 \\
36 \cdot 0 / 52 \cdot 0\end{array}$ & $\begin{array}{l}\text { P26406 } \\
\text { B64099 } \\
\text { U40830 } \\
\text { X16704 }\end{array}$ \\
\hline WlaI & $\begin{array}{l}\text { NeuD } \\
\text { LpxD } \\
\text { LpxD } \\
\text { LpxD }\end{array}$ & $\begin{array}{l}\text { Escherichia coli } \\
\text { Salmonella enterica } \\
\text { Yersinia enterocolitica } \\
\text { Escherichia coli }\end{array}$ & $\begin{array}{l}\text { Polysialic acid capsule synthesis } \\
\text { Acyltransferase } \\
\text { Acyltransferase } \\
\text { Acyltransferase }\end{array}$ & $\begin{array}{l}28 \cdot 1 / 45 \cdot 8 \\
26 \cdot 6 / 44 \cdot 3 \\
26 \cdot 1 / 42 \cdot 0 \\
25 \cdot 1 / 43 \cdot 8\end{array}$ & $\begin{array}{l}\text { U05248 } \\
\text { P18482 } \\
\text { P32203 } \\
\text { P21645 }\end{array}$ \\
\hline WlaK & $\begin{array}{l}\text { RfbE } \\
\text { DegT } \\
\text { FlaA2 } \\
\text { SpsC }\end{array}$ & $\begin{array}{l}\text { Vibrio cholerae } \\
\text { Bacillus stearothermophilus } \\
\text { Caulobacter crescentus } \\
\text { Bacillus subtilus }\end{array}$ & $\begin{array}{l}\text { Perosamine synthetase } \neq \\
\text { Transamination } \\
\text { Motility/polysaccharide } \\
\text { Polysaccharide synthesis }\end{array}$ & $\begin{array}{l}32 \cdot 2 / 51 \cdot 2 \\
29 \cdot 0 / 44 \cdot 4 \\
25 \cdot 9 / 44 \cdot 0 \\
25 \cdot 4 / 43 \cdot 0\end{array}$ & $\begin{array}{l}\text { S28471 } \\
\text { P15263 } \\
\text { U27301 } \\
\text { P39623 }\end{array}$ \\
\hline WlaL & $\begin{array}{l}\text { CapD } \\
\text { TrsG } \\
\text { WpbM }\end{array}$ & $\begin{array}{l}\text { Staphylococcus aureus } \\
\text { Yersinia enterocolitica } \\
\text { Pseudomonas aeruginosa }\end{array}$ & $\begin{array}{l}\text { Capsule synthesis } \\
\text { Acetylgalactosamine synthesis } \neq \\
\text { LPS B-band synthesis }\end{array}$ & $\begin{array}{l}38 \cdot 5 / 55 \cdot 6 \\
37 \cdot 5 / 51 \cdot 7 \\
34 \cdot 4 / 53 \cdot 2\end{array}$ & $\begin{array}{l}\text { P39853 } \\
\text { S51266 } \\
\text { U44089 }\end{array}$ \\
\hline WlaM & $\mathrm{AcfB}$ & Vibrio cholerae & Accessory colonization factor & $26 \cdot 9 / 48 \cdot 2$ & L25660 \\
\hline CheY & $\begin{array}{l}\text { CheY } \\
\text { CheY } \\
\text { CheY } \\
\text { CheY }\end{array}$ & $\begin{array}{l}\text { Campylobacter jejuni } \\
\text { Pseudomonas aeruginosa } \\
\text { Escherichia coli } \\
\text { Salmonella typhimurium }\end{array}$ & $\begin{array}{l}\text { Chemotaxis regulator } \\
\text { Chemotaxis regulator } \\
\text { Chemotaxis regulator } \\
\text { Chemotaxis regulator }\end{array}$ & $\begin{array}{c}100 \\
48 \cdot 4 / 65 \cdot 3 \\
45 \cdot 3 / 57 \cdot 8 \\
45 \cdot 3 / 57 \cdot 8\end{array}$ & $\begin{array}{l}\text { U75208 } \\
\text { S20545 } \\
\text { P06143 } \\
\text { P06657 }\end{array}$ \\
\hline Orf1† & - & - & - & - & - \\
\hline
\end{tabular}

* The program PALIGN from PCGene (Korn \& Queen, 1984) was used to compare the deduced gene products. Open gap cost : 6. Unit gap cost : 2. Percentage similarities represent the sum of identical amino acids (\%) plus conserved substitutions (\%).

† Incomplete.

$\ddagger$ Putative function.

galE. The protein encoded by galE is homologous to UDPgalactose 4-epimerase (GalE), an enzyme catalysing the interconversion between UDPGlc and UDPGal. Gal is a component of the LPS core structure of E. coli and Salmonella typhimurium. Defects in galE result in a rough-LPS phenotype (Rick, 1987). In Neisseria mening- 


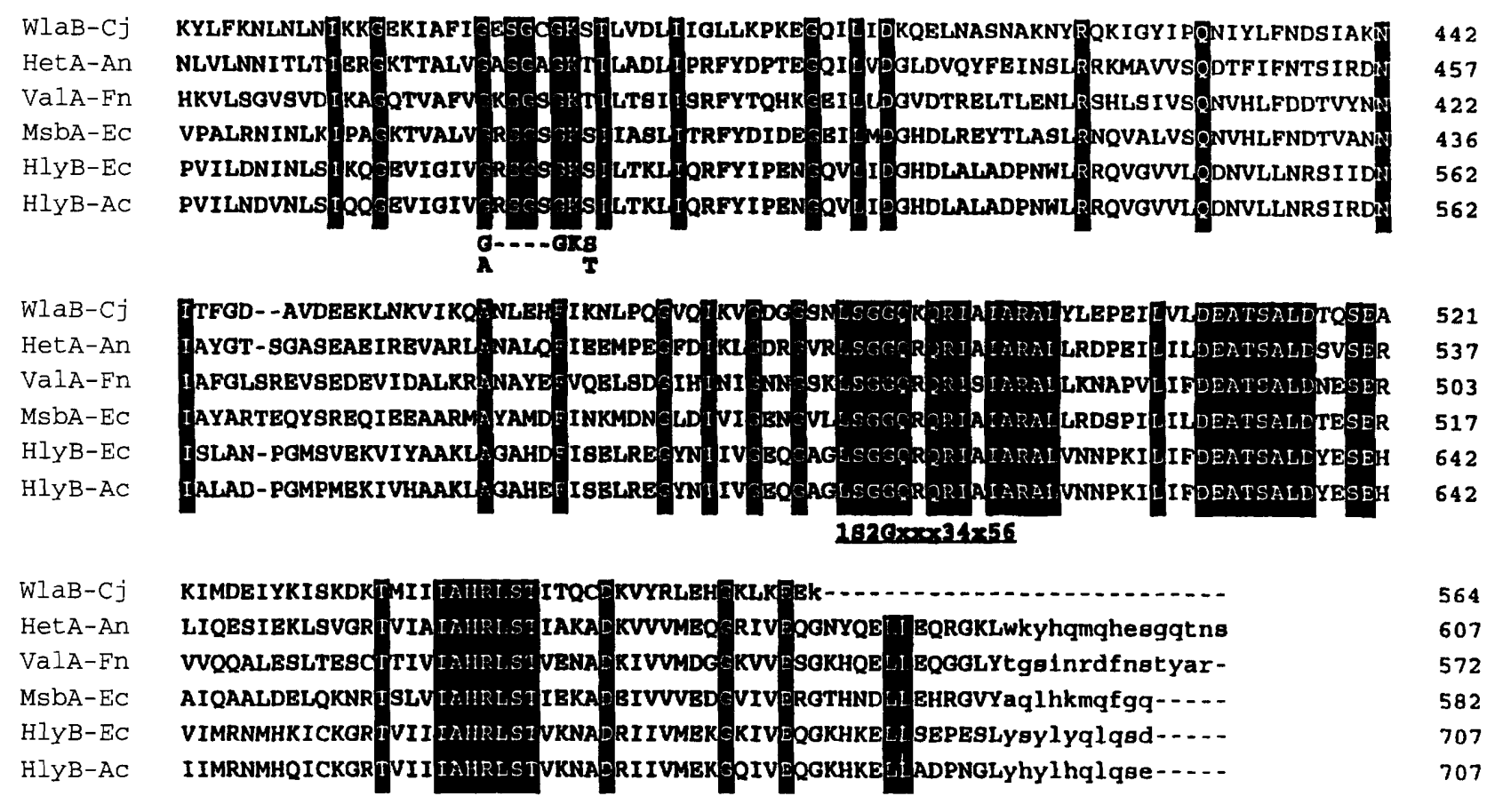

Fig. 5. Alignment of the C-terminal part of WlaB with homologous proteins. Identical amino acids within all six sequences are highlighted. The ATP-binding site motif and the ABC-transporter family signature (underlined) are presented below the alignment. When multiple amino acids are possible in one of the positions of the ABC-transporter family signature, numbers are inserted: $1(L, I, V, M, F$ or $Y) ; 2(S, A$ or $G) ; 3(R, K$ or $A) ; 4(L, I, V, M, Y$ or $A) ; 5(L, I, V, M$ or F); 6 (S, A or G). Cj, C. jejuni; An, Anabaena sp.; Fn, Francisella novicida; Ec, E. coli; AC, Actinobacillus pleuropneumoniae.

itidis, a mutated galE gene resulted in truncation of the LOS chain by deletion of the outer core (Hammerschmidt et al., 1994). The $\mathrm{N}$-terminal region of the predicted GalE protein possesses the consensus NADbinding domain (GxxGxxG; Macpherson et al., 1994) commonly present in epimerases. All known Campylobacter LPS structures contain both Gal and Glc; therefore it is likely that GalE functions as a UDPgalactose 4-epimerase.

wlaB. The protein product of $w l a B$ contains an ATPbinding site and the signature for $A B C$ transporters (Higgins et al., 1990; Walker et al., 1982), suggesting that this protein is involved in transport across the cytoplasmic membrane. The protein contains six potential transmembrane segments, which are also seen in other transmembrane transport molecules (Blight \& Holland, 1990). Homology to other transport proteins is mainly located in the C-terminal part, where the ATPbinding site and the $\mathrm{ABC}$ transporters family motif are located (Fig. 5). WlaB is also homologous to mammalian multidrug resistance proteins ( $\mathrm{P}$-proteins), which bind to and export a variety of drugs, thereby conferring resistance (Endicott \& Ling, 1989). Comparison of the hydrophobicity plots of these proteins indicated that the six transmembrane segments were located at identical positions (data not shown). WlaB probably has a signal peptide which is cleaved between amino acids 45 and 46 . The similarities described above suggest that the WlaB protein from C. jejuni is involved in the transport of LPS molecules across the cytoplasmic membrane.

wlaC, wlaD and wlaE. The protein products of these three genes all possess one or two putative transmembrane segments. All three deduced proteins are similar to putative glycosyltransferases. TrsD and TrsE from Y. enterocolitica, showing homology to $\mathrm{WlaC}$ and $\mathrm{WlaE}$, are putative galactosyl- or $\mathrm{N}$-acetylgalactosaminyltransferases involved in outer core synthesis (Skurnik et al., 1995). WlaC and WlaE are closely related, with $30.2 \%$ identical amino acids and $43.6 \%$ similar amino acids. WlaC and WlaE may link Gal or GalNAc to the growing polysaccharide chain.

wlaF. wlaF is the largest gene found in the cluster, encoding a predicted protein of $82.2 \mathrm{kDa}$ (Table 2). This protein is similar to the transmembrane oligosaccharyltransferases (STT-3) from eukaryotes and the $\mathrm{O}$-antigen polymerase from E. coli. The STT3 protein from yeast is possibly involved in the transfer of an oligosaccharide from a lipid precursor to a protein (Yoshida et al., 1995). The amino acid sequence of WlaF revealed a putative signal peptide, which is most probably cleaved between amino acids 36 and 37, as also seen for the STT-3 protein. The $\mathrm{N}$-terminal part of WlaF contains 12 putative transmembrane segments. The C-terminal part is hydrophilic. These latter two characteristics are also seen in the STT-3 protein. The Rfc polymerase is often also highly hydrophobic, containing 12 putative trans- 


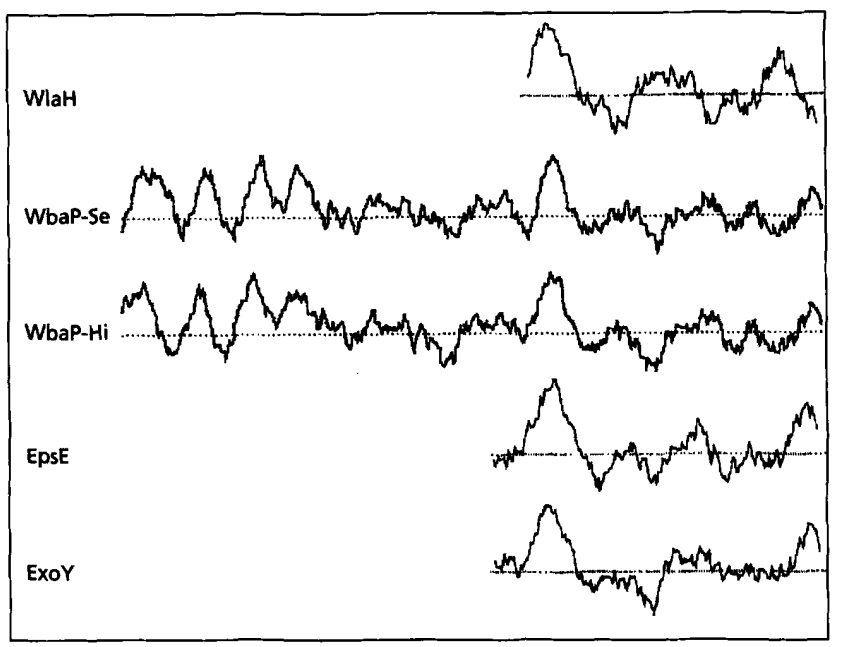

Fig. 6. Hydrophobicity plots of WlaH and homologous proteins (Table 2). The plots were made using SOAP from PCGENE (Korn and Queen, 1984) using an interval of 15 amino acids. Se, $S$. enterica; Hi, Haemophilus influenzae.

membrane segments. We speculate that the C. jejuni WlaF protein is involved in the transfer of oligosaccharides, possibly from a lipid carrier onto the lipid A-core complex. However, it may also have flippase activity. Wzx proteins are also hydrophobic and their genes are often found in LPS gene clusters (Reeves, 1994).

wlaG. Throughout the whole gene, wlaG is homologous to genes encoding galactosyltransferases. The $r f b F$ gene products of Klebsiella pneumoniae and Serratia marcescens, transfer the disaccharide $\mathrm{Gal}(1 \rightarrow 3) \mathrm{Gal}$, representing a single repeating unit of D-galactan I, to the GlcNAc-containing lipid intermediate (Clarke et al., 1995; Szabo et al., 1995). The RfpB protein of Shigella dysenteriae transfers a single $\mathrm{Gal}$ residue to a GlcNAccontaining lipid (Gohmann et al., 1994). Unlike the $\mathrm{RfpB}$ protein of $S$. dysenteriae and the $\mathrm{CpsF}$ protein of Proteus mirabilis (Gygi et al., 1995), the predicted WlaG protein of C. jejuni is probably not membrane bound, as it has no significant hydrophobic regions. However, the $\mathrm{RfbF}$ protein of Klebsiella pneumoniae is also not membrane bound. As at least two galactose residues are present in the LPS molecules of all C. jejuni strains analysed, we suggest that the WlaG protein functions as a galactosyltransferase.

wlat. The $w l a H$ gene is homologous to genes involved in transferring the first sugar of the subunits of $\mathrm{O}$-antigen to the lipid precursor undecaprenol phosphate. The present nomenclature for this type of gene is $w b a P$. This first sugar differs between bacterial species and strains, but in most cases Gal is the first sugar with which $\mathrm{O}$ antigen synthesis is initiated. The proteins showing highest similarity with WlaH transfer a Gal residue. Like other WbaP proteins, WlaH contains a hydrophobic domain required for the interaction with the undecaprenol phosphate lipid carrier (Fig. 6). WbaP-like

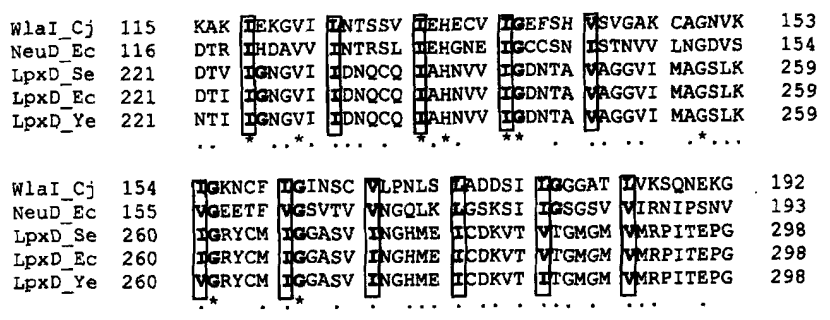

Fig. 7. Protein sequences of Whal and homologous proteins (Table 2). The first residues of the isoleucine patch are boxed and in bold type. Glycine residues in the second position are also in bold face. Asterisks indicate identical amino acids and dots conserved substitutions. $\mathrm{Cj}$, C. jejuni; Ec, E. coli; Se, S. enterica; Ye, $Y$. enterocolitica.

proteins have been shown to be bifunctional, with the above-mentioned transferase activity assigned to the Cterminal domain. Recently it has been proposed that the $\mathrm{N}$-terminal domain of the WbaP protein of Salmonella enterica is involved in the release of undecaprenolpyrophosphate-linked galactose from WbaP (Wang et al., 1996) and does not have a flippase function as earlier reported (Wang \& Reeves, 1994). From the protein alignment it can be concluded that WlaH from C. jejuni probably only possesses the transferase activity, as the $\mathrm{N}$-terminal domain is missing, compared to the $\mathrm{WbaP}$ proteins of S. enterica and Haemophilus influenzae (Fig. 6).

wlal. This ORF, encoding a protein of 203 amino acids, is most similar to the 207 amino acid NeuD protein from $E$. coli, an enzyme involved in the synthesis of the K1 polysaccharide (Annunziato et al., 1995), an $\alpha$-2,8-linked linear polymer of about 200 NeuNAc residues. The $\mathrm{NeuD}$ protein is suggested to be involved in NeuNAc transfer (Annunziato et al., 1995). The C-terminal part of the WlaI protein is also similar, although to a lesser extent, to the 340 amino acid UDP- $N$-acetylglucosamine acyltransferases, LpxD, of E. coli, S. enterica and $Y$. enterocolitica, which play a role in lipid A synthesis (Dicker \& Seetharam, 1991; Hirvas et al., 1990; Vuorio et al., 1994). lpxD-like genes have been found in several gene clusters involved in LPS O-antigen synthesis. The BplB protein from Bordetella pertussis (Allen \& Maskell, 1996) and the WbpD protein from Pseudomonas aeruginosa (Burrows et al., 1996) are both acetyl transferases. The WlaI deduced protein sequence also shows homology to this group of transferases.

A hexapeptide motif, also termed the isoleucine patch (Dicker \& Seetharam, 1992), is present in some transferases (Vaara, 1992). Each motif starts with an isoleucine, leucine or valine residue and often contains a glycine in the second position. In the WlaI protein of C. jejuni, as well as in all the homologous proteins described above, this repeating motif is present (Fig. 7). We propose a function for the WlaI protein as a NeuNAc transferase, since the NeuD protein from E. coli shows the highest similarity. The NeuD protein, like the WlaI protein, is small, containing only 207 amino acids, 
whereas all known LpxD proteins contain around 340 amino acids. The presence of NeuNAc residues in seven of the eight analysed C. jejuni LPS molecules indicates the need of such an enzyme activity.

wlak. The predicted protein designated WlaK shows the highest similarity with the RfbE protein from Vibrio cholerae, which encodes a putative perosamine synthetase (Manning et al., 1995). Homology with DegT from Bacillus stearothermophilus is also found. This protein is required in the pathway to synthesize 2,6-, 3,6and 4,6-dideoxyhexoses and is thought to be an enzyme for transaminations leading to amino sugars (Thorson et al., 1993). The SpsC protein from Bacillus subtilis (Glaser et al., 1993), also belonging to the DegT family, and involved in spore coat polysaccharide biosynthesis, is also homologous to the C. jejuni WlaK protein. The flaA2 gene product from Caulobacter crescentus, involved in flagellin synthesis (B. Ely, personal communication) is also similar to WlaK. It is thought that polysaccharide may be involved in C. crescentus flagellum biogenesis (B. Ely, personal communication). The WlaK protein of C. jejuni is probably also involved in the synthesis of an amino sugar, possibly GalNAc or NeuNAc, which are both common components of the Campylobacter LPS molecule. N. gonorrboeae, however, uses exogenous NeuNAc to sialylate its LOS by an outer-membrane-bound NeuNAc transferase which has been detected in the outer membrane (Mandrell et al., 1993). If exogenous NeuNAc is also used by C. jejuni, no enzymes for the synthesis of NeuNAc would be needed.

wlaL. The WlaL protein is homologous throughout its entire length to the CapD, WbpM and TrsG proteins from Staphylococcus aureus, P. aeruginosa and Y. enterocolitica, respectively (Burrows $e t$ al., 1996; Lin $e t$ al., 1994; Skurnik et al., 1995). All proteins contain five hydrophobic domains in the $\mathrm{N}$-terminal part that are predicted to be transmembrane segments. The central part contains an NAD-binding site and is homologous to UDPglucose 4-epimerases. The function of the CapD protein is not known. The TrsG protein is thought to be involved in the biosynthesis of GalNAc or FucNAc (acetylfucosamine), the WbpM protein is possibly a dehydrogenase or epimerase needed for the biosynthesis of a 2-acetamido-2,6-dideoxy-D-galactose residue. A putative signal peptide has been found in WlaL, which is probably cleaved at position 29 . We suggest the WlaL protein is involved in the synthesis of an amino sugar, probably GalNAc or NeuNAc.

wlaM. The $w$ laM gene product shows only low similarity to an accessory colonization factor, AcfB (Everiss et al., 1994). This protein contains the methyl-accepting chemotaxis motif as found in chemotaxis genes (Alley et al., 1992; Dahl et al., 1989). However the similarity with WlaM was confined to the N-terminal part not containing this motif. Like WlaF, WlaM is a hydrophobic protein containing six putative transmembrane regions. Therefore WlaM could also function as a flippase or a polymerase.

cheY. This gene is identical to the cheY gene of C. jejuni
(Ketley, 1997; Yao et al., 1997), a gene involved in chemotaxis. It is unlikely that this gene is an LPS synthesis gene. Furthermore, unlike galE and wla, the che $Y$ gene has its own promoter consensus sequence.

orf1. No homology was found for this incomplete ORF or its putative protein product.

\section{DISCUSSION}

We have shown that a $16 \mathrm{~kb}$ chromosomal DNA region of Campylobacter jejuni strain 81116 is able to express LPS in E. coli. These heat-stable antigens are known to react with Penner 6 antiserum. The sequence analysis of this region is presented.

\section{The wla cluster}

The sequence data show that the $16 \mathrm{~kb}$ region contains 11 genes, of which the deduced protein sequences show homology to proteins involved in LPS synthesis in other bacteria. On the basis of the observed similarity of the deduced Wla proteins to proteins involved in LOS synthesis, and especially the outer-core synthesis of Y. enterocolitica and Bordetella pertussis (Allen \& Maskell, 1996; Skurnik et al., 1995), it is likely that the wla gene cluster of C. jejuni is involved in the synthesis of the $\mathrm{O}$-antigen-like polysaccharide, as well as the outer core, but not of the inner core. This is in agreement with the finding of the waaC gene, situated at the beginning of a separate gene cluster of at least five genes involved in inner core synthesis (data not shown).

The presence of the $w$ laH gene, which probably encodes a galactosyltransferase, linking a Gal residue to the lipid carrier, and the observation that almost all analysed outer core molecules from C. jejuni start with a Gal residue, suggests that the outer core molecule is synthesized on a lipid carrier. This has also been suggested for the outer core of Y. enterocolitica, where also a Gallipid carrier transferase gene was found to be present in the outer-core-synthesis gene cluster (Skurnik et al., 1995). Both the O-antigen-like polysaccharide and the outer core may be synthesized on lipid carriers, in which case the WlaH protein would catalyse the first step.

\section{Sugar biosynthesis}

Three genes involved in the biosynthesis of sugars are present in the wla cluster. The presence of galE, converting Glc to Gal, is not surprising, as all known outer core molecules of $\mathrm{C}$. jejuni contain $\mathrm{Gal}$ residues. The $w l a K$ and wlaL genes are probably involved in the synthesis of amino sugars. GalNAc and NeuNAc are amino sugars found in core molecules of several $C$. jejuni strains.

\section{Transport of sugar structures}

Three transport steps have been observed during LPS synthesis of E. coli and Salmonella typhimurium: flipping of an oligosaccharide subunit attached to a lipid carrier across the inner membrane; transport of saccharide structures from a lipid carrier to the 
lipid A-core complex; and transport of the complete LPS molecule from the inner membrane to the outer membrane.

We assume that the outer-core molecule of C. jejuni is synthesized at the cytoplasmic side of the inner membrane, like an LPS O-antigen subunit. After completion it has to be 'flipped' to the periplasmic side of the inner membrane. This could happen before or after it has been ligated to the lipid A-inner core complex. Possibly WlaM is involved in this flippase process and $\mathrm{WlaF}$ could be used to link the outer core to the lipid A-inner core complex, or vice versa. The complete LOS molecule is then translocated across the inner membrane to the outer membrane by WlaB.

\section{Sugar transferases}

The proposed sugar transferases within the wla gene cluster consist of Gal or GalNAc transferases WlaC and WlaE, an unknown transferase WlaD, a Gal transferase WlaG, a Gal-to-lipid-carrier transferase WlaH and a NeuNAc transferase WlaI. If, as suggested above, the outer core is synthesized on a lipid carrier, WlaH probably initiates the synthesis of the outer core by transferring a Gal residue onto the lipid carrier.

All but one of the known core molecules of C. jejuni contain a GalNAc residue bound to a backbone $\mathrm{Gal}$ residue. The proposed function of $\mathrm{WlaC}$ and $\mathrm{WlaE}$ as GalNAc transferases would predict the presence of a GalNAc residue in the outer core of strain 81116. Most Gal residues in the outer core molecules of $C$. jejuni are branched with a NeuNAc residue, for which WlaI is the proposed transferase.

\section{O-antigen-like polysaccharide structure and synthesis}

Three observations suggest that the $\mathrm{O}$-antigen-like repeat of C. jejuni is not linked to the lipid A-inner core complex and therefore is not a proper O-antigen. (1) Significant amounts of lipid A-inner core residues were not found in any of the analysed $\mathrm{O}$-antigen-like repeats (Aspinall et al., 1993b, c, 1994b, 1995a ; Salloway et al., 1996). (2) The O-antigen-like repeat unit is not stained by the silver-staining method, whereas the lipid A-core complex is. Thus, if the repeat unit were linked to the lipid A-core complex it would surely be seen using this technique. (3) Expression of the wla cluster in E. coli shows a lipid A-core molecule larger than that of Campylobacter, which reacts with the serospecific antiserum of C. jejuni 81116. This suggests that the lipid A-core complex of $E$. coli is used, to which a specific $C$. jejuni sugar structure is linked. The molecular mass of the expressed $\mathrm{O}$-antigen-like repeat, however, is not increased. The $\mathrm{O}$-antigen-like repeat therefore resembles capsular polysaccharide or enterobacterial common antigen as found in E. coli and not LPS Oantigen.

Three variable $\mathrm{O}$-antigen-like polysaccharides from different Campylobacter strains have been examined. Two consist of a disaccharide and one of a trisaccharide repeat. In two of these repeat units, a heptose derivative is present, as also found in Campylobacter coli $\mathrm{O}: 30$ (Aspinall et al., 1993a) and in strains of Campylobacter lari (Aspinall et al., 1995b, 1995c). In all three analysed repeat units, an amino sugar is present; in two of these it is a GlcNAc residue.

We predict that the polysaccharide synthesis follows the same route as the start of the outer-core assembly, namely on a lipid carrier. The first sugar, a Gal residue, will be linked by WlaH. After this, the synthesis of the outer core and the $\mathrm{O}$-antigen-like polysaccharide would diverge.

When comparing the known $\mathrm{O}$-antigen-like polysaccharide structures with the core structures of $C$. jejuni, a remarkable difference is seen. The Gal residues in the repeat units are not sialylated, whereas all Gal residues found in the backbone of the outer core molecule are. It could therefore be reasoned that the outer core oligosaccharide is sialylated in a compartment where the $\mathrm{O}$-antigen-like polysaccharide is not present. Sialylation may occur on the periplasmic side of the inner membrane or in the outer membrane, where the $\mathrm{O}$-antigen-like polysaccharide never goes.

The characterization of this first wla gene cluster of $C$. jejuni marks a starting point for further studies and applications, possibly in serotyping, diagnostics and vaccine development. Also the study of LPS-induced diseases can be advanced.

Insertional-inactivation experiments in C. jejuni and in the cloned $w l a$ region in $E$. coli are needed to confirm the functions assigned to the various proteins. In addition, attempts to complement defined $S$. typhimurium LPS mutants are in progress. The LOS structure of C. jejuni 81116 is currently being analysed by Dr A. P. Moran and coworkers in Galway, Ireland.

\section{ACKNOWLEDGEMENTS}

We are grateful to Dr D. G. Newell for her gift of the Penner 6 antiserum and to Dr J. M. Ketley for his help with designing Fig. 1. We thank Dr P. R. Reeves for his help with the gene nomenclature. We thank A. J. A. M. van Asten, L. Heijmenvan Dijk and K. A. Zwaagstra for technical assistance with the automated sequencing.

\section{REFERENCES}

Allen, A. \& Maskell, D. (1996). The identification, cloning and mutagenesis of a genetic locus required for lipopolysaccharide biosynthesis in Bordetella pertussis. Mol Microbiol 19, 37-52.

Allen, L. N. \& Hanson, R. S. (1985). Construction of broad-hostrange cosmid cloning vectors: identification of genes necessary for growth of Methylobacterium organophilum on methanol. $J$ Bacteriol 161, 955-962.

Alley, M. R., Maddock, J. R. \& Shapiro, L. (1992). Polar localization of a bacterial chemoreceptor. Genes Dev 6, 825-836.

Altschul, S. F., Gish, W., Miller, W., Myers, E. W. \& Lipman, D. J. (1990). Basic local alignment search tool. J Mol Biol 215, 403-410.

Annunziato, P. W., Wright, L. F., Vann, W. F. \& Silver, R. P. (1995). Nucleotide sequence and genetic analysis of the neuD and neuB genes in region 2 of the polysialic acid gene cluster of Escherichia coli K1. J Bacteriol 177, 312-319. 
Aspinall, G. O., McDonald, A. G. \& Pang, H. (1992a). Structures of the $\mathrm{O}$ chains from lipopolysaccharides of Campylobacter jejuni serotypes O:23 and O:36. Carbohydr Res 231, 13-30.

Aspinall, G. O., McDonald, A. G., Raju, T. S., Pang, H., Mills, S. D., Kurjanczyk, L. A. \& Penner, J. L. (1992b). Serological diversity and chemical structures of Campylobacter jejuni low-molecularweight lipopolysaccharides. J Bacteriol 174, 1324-1332.

Aspinall, G. O., McDonald, A. G., Pang, H., Kurjanczyk, L. A. \& Penner, J. L. (1993a). An antigenic polysaccharide from Campylobacter coli serotype O:30: structure of a teichoic acid-like antigenic polysaccharide associated with the lipopolysaccharide. $J$ Biol Chem 268, 18321-18329.

Aspinall, G. O., McDonald, A. G., Raju, T. S., Pang, H., Kurjanczyk, L. A., Penner, J. L. \& Moran, A. P. (1993b). Chemical structure of the core region of Campylobacter jejuni serotype 0:2 lipopolysaccharide. Eur J Biochem 213, 1029-1037.

Aspinall, G. O., McDonald, A. G., Raju, T. S., Pang, H., Moran, A. P. \& Penner, J. L. (1993c). Chemical structures of the core regions of Campylobacter jejuni serotypes $\mathrm{O}: 1, \mathrm{O}: 4, \mathrm{O}: 23$, and O:36 lipopolysaccharides. Eur $J$ Biochem 213, 1017-1027 (erratum published in Eur J Biochem 216, 880).

Aspinall, G. O., McDonald, A. G. \& Pang, H. (1994a). Lipopolysaccharides of Campylobacter jejuni serotype $\mathrm{O}: 19$ : structures of $\mathrm{O}$ antigen chains from the serostrain and two bacterial isolates from patients with the Guillain-Barré syndrome. Biochemistry 33, 250-255.

Aspinall, G. O., McDonald, A. G., Pang, H., Kurjanczyk, L. A. \& Penner, J. L. (1994b). Lipopolysaccharides of Campylobacter jejuni serotype O:19: structures of core oligosaccharide regions from the serostrain and two bacterial isolates from patients with the Guillain-Barré syndrome. Biochemistry 33, 241-249.

Aspinall, G. O., Lynch, C. M., Pang, H., Shaver, R. T. \& Moran, A. P. (1995a). Chemical structures of the core region of Campylobacter jejuni O:3 lipopolysaccharide and an associated polysaccharide. Eur J Biochem 231, 570-578.

Aspinall, G. O., Monteiro, M. A. \& Pang, H. (1995b). Lipooligosaccharide of the Campylobacter lari type strain ATCC 35221. Structure of the liberated oligosaccharide and an associated extracellular polysaccharide. Carbohydr Res 279, 245-264.

Aspinall, G. O., Monteiro, M. A., Pang, H., Kurjanczyk, L. A. \& Penner, J. L. (1995c). Lipo-oligosaccharide of Campylobacter lari strain PC 637. Structure of the liberated oligosaccharide and an associated extracellular polysaccharide. Carbohydr Res 279, 227-244.

Ausubel, F. M., Brent, R., Kingston, R. E., Moore, D. D., Seidman, J. G., Smith, J.A. \& Struhl, K. (1995). Current Protocols in Molecular Biology. New York: John Wiley.

Blaser, M. J. \& Reller, L. B. (1981). Campylobacter enteritis. $N$ Engl J Med 305, 1444-1452.

Blight, M. A. \& Holland, I. B. (1990). Structure and function of haemolysin B, P-glycoprotein and other members of a novel family of membrane translocators. Mol Microbiol 4, 873-880.

Bolivar, F., Rodriguez, R. L., Greene, P. J., Betlach, M. C., Heyneker, H. L. \& Boyer, H. W. (1977). Construction and characterization of new cloning vehicles. II. A multipurpose cloning system. Gene 2, 95-113.

Boyer, H. W. \& Roulland-Dussoix, D. (1969). A complementation analysis of the restriction and modification of DNA in Escherichia coli. J Mol Biol 41, 459-472.

Branquinho, M. R., Alviano, C. S. \& Ricciardi, I. D. (1983). Chemical composition and biological action of lipopolysac- charide (LPS) of Campylobacter fetus ss. jejuni. Rev Microbiol 14, 90-96.

Bray, J. (1945). Isolation of antigenically homogeneous strains of Bact. coli neapolitanum from summer diarrhoea in infants. $J$ Patbol Bacteriol 57, 239-247.

Burrows, L. L., Charter, D. F. \& Lam, J. S. (1996). Molecular characterization of the Pseudomonas aeruginosa serotype O5 (PAO1) B-band lipopolysaccharide gene cluster. Mol Microbiol 22, 481-495.

Butzler, J. P. \& Skirrow, M. B. (1979). Campylobacter enteritis. Clin Gastroenterol 8, 737-765.

Clarke, B. R., Bronner, D., Keenleyside, W. J., Severn, W. B., Richards, J. C. \& Whitfield, C. (1995). Role of Rfe and RfbF in the initiation of biosynthesis of D-galactan I, the lipopolysaccharide $\mathrm{O}$ antigen from Klebsiella pneumoniae serotype O1. J Bacteriol 177, 5411-5418.

Dahl, M. K., Boos, W. \& Manson, M. D. (1989). Evolution of chemotactic-signal transducers in enteric bacteria. J Bacteriol 171, 2361-2371.

Demarco de Hormaeche, R., Macpherson, A., Bowe, F. \& Hormaeche, C. E. (1991). Alterations of the LPS determine virulence of Neisseria gonorrhoeae in guinea-pig subcutaneous chambers. Microb Pathog 11, 159-170.

Dicker, I. B. \& Seetharam, S. (1991). Cloning and nucleotide sequence of the firA gene and the firA200(Ts) allele from Escherichia coli. J Bacteriol 173, 334-344.

Dicker, I. B. \& Seetharam, S. (1992). What is known about the structure and function of the Escherichia coli protein FirA? Mol Microbiol 6, 817-823.

Endicott, J. A. \& Ling, V. (1989). The biochemistry of Pglycoprotein-mediated multidrug resistance. Annu Rev Biochem 58, 137-171.

Everiss, K. D., Hughes, K. J., Kovach, M. E. \& Peterson, K. M. (1994). The Vibrio cholerae acfB colonization determinant encodes an inner membrane protein that is related to a family of signal-transducing proteins. Infect Immun 62, 3289-3298.

Glaser, P., Kunst, F., Arnaud, M. \& 17 other authors (1993). Bacillus subtilis genome project: cloning and sequencing of the $97 \mathrm{~kb}$ region from 325 degrees to 333 degrees. Mol Microbiol 10, 371-384.

Gohmann, S., Manning, P. A., Alpert, C. A., Walker, M. J. \& Timmis, K. N. (1994). Lipopolysaccharide O-antigen biosynthesis in Shigella dysenteriae serotype 1: analysis of the plasmid-carried rfp determinant. Microb Pathog 16, 53-64.

Gygi, D., Rahman, M. M., Lai, H. C., Carlson, R., Guard-Petter, J. \& Hughes, C. (1995). A cell-surface polysaccharide that facilitates rapid population migration by differentiated swarm cells of Proteus mirabilis. Mol Microbiol 17, 1167-1175.

Hackett, J., Wyk, P., Reeves, P. \& Mathan, V. (1987). Mediation of serum resistance in Salmonella typhimurium by an 11-kilodalton polypeptide encoded by the cryptic plasmid. J Infect Dis 155 , 540-549.

Hammerschmidt, S., Birkholz, C., Zahringer, U., Robertson, B. D., van Putten, J., Ebeling, O. \& Frosch, M. (1994). Contribution of genes from the capsule gene complex (cps) to lipooligosaccharide biosynthesis and serum resistance in Neisseria meningitidis. Mol Microbiol 11, 885-896.

Hanahan, D. (1983). Studies on transformation of Escherichia coli with plasmids. J Mol Biol 166, 557-580.

Higgins, C. F., Hyde, S. C., Mimmack, M. M., Gileadi, U., Gill, D. R. \& Gallagher, M. P. (1990). Binding protein-dependent transport systems. J Bioenerg Biomembr 22, 571-592. 
Hirvas, L., Koski, P. \& Vaara, M. (1990). Primary structure and expression of the Ssc-protein of Salmonella typhimurium. Biochem Biophys Res Commun 173, 53-59 (erratum published in Biochem Biophys Res Commun 174, 1054).

Inzana, T. J., Seifert, W. E., Jr \& Williams, R. P. (1985). Composition and antigenic activity of the oligosaccharide moiety of Haemophilus influenzae type b lipooligosaccharide. Infect Immun 48, 324-330.

Jansson, P. E., Lindberg, A. A., Lindberg, B. \& Wollin, R. (1981). Structural studies on the hexose region of the core in lipopolysaccharides from Enterobacteriaceae. Eur $J$ Biochem 115, 571-577.

Jennings, H. J., Bhattacharjee, A. K., Kenne, L., Kenny, C. P. \& Calver, G. (1980). The R-type lipopolysaccharides of Neisseria meningitidis. Can J Biochem 58, 128-136.

Joiner, K. A., Grossman, N., Schmetz, M. \& Leive, L. (1986). C3 binds preferentially to long-chain lipopolysaccharide during alternative pathway activation by Salmonella montevideo. J Immunol 136, 710-715.

Ketley, J. M. (1997). Pathogenesis of enteric infection by Campylobacter. Microbiology 143, 5-21.

Korn, L. J. \& Queen, C. (1984). Analysis of biological sequences on small computers. DNA 3, 421-436.

Korolik, V., Fry, B. N., Alderton, M. R., van der Zeijst, B. A. M. \& Coloe, P. J. (1997). Expression of Campylobacter byoilei lipooligosaccharide (LOS) antigens in Escherichia coli. Microbiology 143, 3481-3489.

Laemmli, U. K. (1970). Cleavage of structural proteins during the assembly of the head of bacteriophage T4. Nature 227, 680-685.

Lawrence, C. E., Altschul, S. F., Boguski, M. S., Liu, J. S., Neuwald, A. F. \& Wootton, J. C. (1993). Detecting subtle sequence signals : a Gibbs sampling strategy for multiple alignment. Science 262, 208-214.

Lesse, A. J., Campagnari, A. A., Bittner, W. E. \& Apicella, M. A. (1990). Increased resolution of lipopolysaccharides and lipooligosaccharides utilizing tricine-sodium dodecyl sulfate-polyacrylamide gel electrophoresis. J Immunol Methods 126, 109-117.

Lin, W. S., Cunneen, T. \& Lee, C. Y. (1994). Sequence analysis and molecular characterization of genes required for the biosynthesis of type 1 capsular polysaccharide in Staphylococcus aureus. J Bacteriol 176, 7005-7016.

Lugtenberg, B., Meijers, J., Peters, R., van der Hoek, P. \& van Alphen, L. (1975). Electrophoretic resolution of the "major outer membrane protein' of Escherichia coli K12 into four bands. FEBS Lett 58, 254-258.

Macpherson, D. F., Manning, P. A. \& Morona, R. (1994). Characterization of the dTDP-rhamnose biosynthetic genes encoded in the rfb locus of Shigella flexneri. Mol Microbiol 11, 281-292.

McSweegan, E. \& Walker, R. I. (1986). Identification and characterization of two Campylobacter jejuni adhesins for cellular and mucous substrates. Infect Immun 53, 141-148.

Mandrell, R. E. \& Apicella, M. A. (1993). Lipo-oligosaccharides (LOS) of mucosal pathogens: molecular mimicry and hostmodification of LOS. Immunobiology 187, 382-402.

Mandrell, R. E., Smith, H., Jarvis, G. A., Griffiss, J. M. \& Cole, J. A. (1993). Detection and some properties of the sialyltransferase implicated in the sialylation of lipopolysaccharide of Neisseria gonorrhoeae. Microb Pathog 14, 307-313.

Manning, P. A., Stroeher, U. H., Karageorgos, L. E. \& Morona, R. (1995). Putative O-antigen transport genes within the $\mathrm{rfb}$ region of Vibrio cholerae $\mathrm{O} 1$ are homologous to those for capsule transport. Gene 158, 1-7.
Mills, S. D., Kuzniar, B., Shames, B., Kurjanczyk, L. A. \& Penner, J. L. (1992). Variation of the $O$ antigen of Campylobacter jejuni in vivo. $J$ Med Microbiol 36, 215-219.

Moxon, R.E. \& Maskell, D. (1992). Haemophilus influenzae lipopolysaccharide: the biochemistry and biology of a virulence factor. In Molecular Biology of Bacterial Infection: Current Status and Future Perspectives, pp. 75-96. Edited by C. E. Hormaeche, C. W. Penn \& C. J. Smyth. Cambridge: Cambridge University Press.

Naess, V. \& Hofstad, T. (1984). Chemical composition and biological activity of lipopolysaccharides prepared from type strains of Campylobacter jejuni and Campylobacter coli. Acta Pathol Microbiol Immunol Scand Sect B Microbiol 92, 217-222.

Neuhard, J. \& Thomassen, E. (1976). Altered deoxyribonucleotide pools in P2 eductants of Escherichia coli K-12 due to deletion of the dcd gene. J Bacteriol 126, 999-1001.

Newell, D. G., McBride, H. \& Dolby, J. M. (1985). Investigations on the role of flagella in the colonization of infant mice with Campylobacter jejuni and attachment of Campylobacter jejuni to human epithelial cell lines. J Hyg 95, 217-227.

Palmer, S. R., Gully, P. R., White, J. M., Pearson, A. D., Suckling, W. G., Jones, D. M., Rawes, J. C. \& Penner, J. L. (1983). Waterborne outbreak of campylobacter gastroenteritis. Lancet 1 , 287-290.

Pavliak, V., Brisson, J. R., Michon, F., Uhrin, D. \& Jennings, H. J. (1993). Structure of the sialylated L3 lipopolysaccharide of Neisseria meningitidis. J Biol Chem 268, 14146-14152.

Penner, J. L. (1988). The genus Campylobacter: a decade of progress. Clin Microbiol Rev 1, 157-172.

Penner, J. L. \& Hennessy, J. N. (1980). Passive hemagglutination technique for serotyping Campylobacter fetus subsp. jejuni on the basis of soluble heat-stable antigens. J Clin Microbiol 12, 732-737.

Preston, M. A. \& Penner, J. L. (1987). Structural and antigenic properties of lipopolysaccharides from serotype reference strains of Campylobacter jejuni. Infect Immun 55, 1806-1812.

Ray, A., Redhead, K., Selkirk, S. \& Poole, S. (1991). Variability in LPS composition, antigenicity and reactogenicity of phase variants of Bordetella pertussis. FEMS Microbiol Lett 63, 211-217.

Ray, B. L. \& Raetz, C. R. (1987). The biosynthesis of gram-negative endotoxin. A novel kinase in Escherichia coli membranes that incorporates the $4^{\prime}$-phosphate of lipid A. J Biol Chem 262, 1122-1128.

Reeves, P. R. (1994). Biosynthesis and assembly of lipopolysaccharide. In Bacterial Cell Wall, pp. 281-317. Edited by J.-M. Ghuysen \& R. Hakenbeck. Amsterdam: Elsevier.

Reeves, P. R., Hobbs, M., Valvano, M. A. \& 8 other authors (1996). Bacterial polysaccharide synthesis and gene nomenclature. Trends Microbiol 4, 495-503.

Rick, P. D. (1987). Lipopolysaccharide biosynthesis. In Escherichia coli and Salmonella typhymurium: Cellular and Molecular Biology, pp. 648-662. Edited by F. C. Neidhart and others. Washington, DC: American Society for Microbiology.

Salloway, S., Mermel, L. A., Seamans, M., Aspinall, G. O., Nam Shin, J. E., Kurjanczyk, L. A. \& Penner, J. L. (1996). Miller-Fisher syndrome associated with Campylobacter jejuni bearing lipopolysaccharide molecules that mimic human ganglioside GD3. Infect Immun 64, 2945-2949.

Sambrook, J., Fritsch, E. F. \& Maniatis, T. (1982). Molecular Cloning: a Laboratory Manual. Cold Spring Harbor, NY: Cold Spring Harbor Laboratory. 
Sanger, F., Nicklen, S. \& Coulson, A. R. (1977). DNA sequencing with chain-terminating inhibitors. Proc Natl Acad Sci USA 74, 5463-5467.

Schagger, H. \& von Jagow, G. (1987). Tricine-sodium dodecyl sulfate-polyacrylamide gel electrophoresis for the separation of proteins in the range from 1 to $100 \mathrm{kDa}$. Anal Biochem 166, 368-379.

Schnaitman, C. A. \& Klena, J. D. (1993). Genetics of lipopolysaccharide biosynthesis in enteric bacteria. Microbiol Rev 57, 655-682.

Schwerer, B., Neisser, A., Polt, R. J., Bernheimer, H. \& Moran, A. P. (1995). Antibody cross-reactivities between gangliosides and lipopolysaccharides of Campylobacter jejuni serotypes associated with Guillain-Barré syndrome. J Endotoxin Res 2, 395-403.

Short, J. M., Fernandez, J. M., Sorge, J. A. \& Huse, W. D. (1988). Lambda ZAP: a bacteriophage lambda expression vector with in vivo excision properties. Nucleic Acids Res 16, 7583-7600.

Skirrow, M. B. (1977). Campylobacter enteritis: a 'new' disease. Br Med J 2, 9-11.

Skurnik, M., Venho, R., Toivanen, P. \& al-Hendy, A. (1995). A novel locus of Yersinia enterocolitica serotype $0: 3$ involved in lipopolysaccharide outer core biosynthesis. Mol Microbiol 17, 575-594.

Stern, N. J., Bailey, J. S., Blankenship, L. C., Cox, N. A. \& McHan, F. (1988). Colonization characteristics of Campylobacter jejuni in chick ceca. Avian Dis 32, 330-334.

Stinavage, P., Martin, L. E. \& Spitznagel, J. K. (1989). O antigen and lipid A phosphoryl groups in resistance of Salmonella typhimurium LT-2 to nonoxidative killing in human polymorphonuclear neutrophils. Infect Immun 57, 3894-3900.

Szabo, M., Bronner, D. \& Whitfield, C. (1995). Relationships between $r f b$ gene clusters required for biosynthesis of identical $D$ galactose-containing $\mathrm{O}$ antigens in Klebsiella pneumoniae serotype O1 and Serratia marcescens serotype O16. J Bacteriol 177, 1544-1553.

Tauxe, R. V. (1992). Epidemiology of Campylobacter jejuni infections in the United States and other industrialized nations. In Campylobacter jejuni: Current Status and Future Trends, pp. 9-19. Edited by I. Nachamkin, M. J. Blaser \& L. S. Tompkins. Washington, DC: American Society for Microbiology.
Thorson, J. S., Lo, S. F. \& Liu, H.-W. (1993). Biosynthesis of 3, 6dideoxyhexoses: new mechanistic reflections upon 2,6-dideoxy, 4,6-dideoxy, and amino sugar construction. J Am Chem Soc 115, 6993-6994.

Tsai, C. M. \& Frasch, C. E. (1982). A sensitive silver stain for detecting lipopolysaccharides in polyacrylamide gels. Anal Biochem 119, 115-119.

Vaara, M. (1992). Eight bacterial proteins, including UDP-Nacetylglucosamine acyltransferase (LpxA) and three other transferases of Escherichia coli, consist of a six-residue periodicity theme. FEMS Microbiol Lett 76, 249-254.

Vuorio, R., Harkonen, T., Tolvanen, M. \& Vaara, M. (1994). The novel hexapeptide motif found in the acyltransferases LpxA and LpxD of lipid A biosynthesis is conserved in various bacteria. FEBS Lett 337, 289-292.

Walker, J. E., Saraste, M., Runswick, M. J. \& Gay, N. J. (1982). Distantly related sequences in the alpha- and beta-subunits of ATP synthase, myosin, kinases and other ATP-requiring enzymes and a common nucleotide-binding fold. $E M B O \mathrm{~J}$ 1, 945-951.

Wang, L. \& Reeves, P. R. (1994). Involvement of the galactosyl-1phosphate transferase encoded by the Salmonella enterica rfbP gene in O-antigen subunit processing. J Bacteriol 176, 4348-4356.

Wang, L., Liu, D. \& Reeves, P. R. (1996). C-terminal half of Salmonella enterica $\mathrm{WbaP}$ ( $\mathrm{RfbP}$ ) is the galactosyl-1-phosphate transferase domain catalyzing the first step of $\mathrm{O}$-antigen synthesis. J Bacteriol 178, 2598-2604.

Yanisch-Perron, C., Vieira, J. \& Messing, J. (1985). Improved M13 phage cloning vectors and host strains: nucleotide sequences of the M13mp18 and pUC19 vectors. Gene 33, 103-119.

Yao, R., Burr, D. H. \& Guerry, P. (1997). CheY-mediated modulation of Campylobacter jejuni virulence. Mol Microbiol 23, 1021-1031.

Yoshida, S., Ohya, Y., Nakano, A. \& Anraku, Y. (1995). STT3, a novel essential gene related to the PKC1/STT1 protein kinase pathway, is involved in protein glycosylation in yeast. Gene 164 , $167-172$.

Received 10 October 1997; revised 13 March 1998; accepted 2 April 1998. 